\title{
Synthesis of Bis-pyridinium Oxime Antidotes Using Bis(methylsulfonoxymethyl) Ether for Organophosphate Nerve Agents
}

\author{
Garp Yeol Yang, Joong-Ho Yoon, Churl-Min Seong, No-Sang Park, and Young-Sik Jung" \\ Medicinal Science Division. Korea Research Insitute of Chemical Technology, \\ P.O. Box 107, Yusong, Daejeon 305-606, Korea \\ Recened Mor' 7.2003
}

Key Words : Bis-pyridinium oxime antidotes, Bis(methylsulfonoxymethyl) ether, Organophosphate nerve agents, BCME

Organophospate nerve agents are organic esters of phosphorous-based acid derivatives and they are extremely toxic chemicals that were first developed before and during World War 11 primarily for military use. Five organophosphates are generally regarded as nerve agents. They are commonly known as dimethylphosphoramidocyanidic acid ethyl ester (tabun), methylphosphonofluoridic acid (1methylethyl) ester (sarin), methylphosphonofluoridic acid 1,2,2-trimethylpropyl ester (soman), methylphosphonofluoridic acid cyclohexyl ester (cyclosarin), and methylphosphonothioic acid $\mathrm{S}$-[2-[bis(1-methylethyl)amino] ethyl] Oethyl ester (VX). Nerve agents are compounds that exert their biological effects by inhibition of the enzyme acetylcholinesterase (AChF), found at the receptor sites of tissue innervated by the cholinergic nervous system, which hydroIyzes acetylcholine $\left(\mathrm{ACh}_{1}\right)$ very rapidly.' The acute toxicity of organophospate compounds in mammals is generally believed to be due to their irreversible inhibition of $\mathrm{ACh \Gamma}$, Among these organophospate nerve agents, soman is probably one of the most dangerous organophospate agents since its deleterious effects are especially difficult to counteract. $^{2}$ Soman seems to cause centrally mediated seizure activity that can rapidly contribute to profound brain damage.<smiles>CCOP(C)(=O)N(C)C</smiles>

Tabun

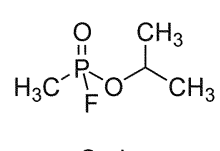

Sarin

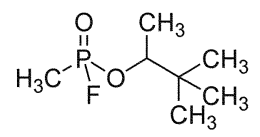

Soman
Current medical protection against the toxicity of organophospate compounds consists of a regimen of anticholinergic drugs, such as atropine, to counteract the accumulation of acetylcholine and oximes to reactivate organophospate-inhibited AChE..$^{3}$ It is clearly important that acetylcholinesterase reactivators should be available as antidotes of poisoning by such compounds. One of the most widely used is pralidoxime (2-PAM). Unfortunately, the presently used antidote, such as pralidoxime in combination with atropine, does not appear to ameliorate soman-induced toxic signs. Some bis-pyridinium oximes are known to be acetylcholinesterase reactivators and effective antidotes in intoxication with organophosphates. ${ }^{4}$ 'The most important standard oximes are toxogonin, $\mathrm{Hl}-6$ and $\mathrm{HGG}-12$. Although pyridinium oximes like 2-PAM can not reactivate soman-inlibited AChE, bis-pyridium oximes like HI-6 have been found to be effective reactivators of non-aged somaninhibited human $\mathrm{ACh}$.

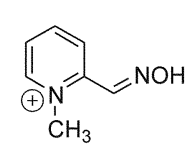

2-PAM

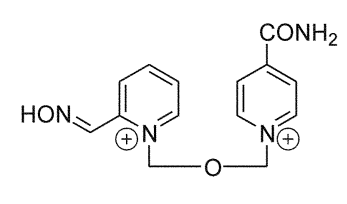

HI-6

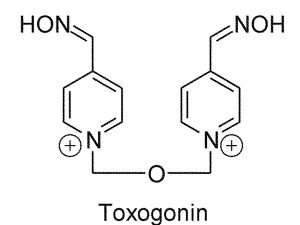

Toxogonin
In their manufacture, the bis-pyridinium oximes require the use of bis(chloromethyl) ether (BCMГ), Recently, however, ВCМГ has been found to be such a potent carcinogen that it is no longer commercially available. For safe handling, human beings simply must not be exposed to this substance in any concentration, no matter how slight it may be. Consequently, there is a need for a less volatile reagent for use in manufacturing nerve agent antidotes. There is a further need to replace BCMF: in nerve agent antidote production with a non-carcinogenic material. Bis(methylsulfonoxymethyl) ether, which is non-carcinogenic is substituted for the BCMГ: in the production of bispyridinium oximes.<smiles>ClCOCCl</smiles>

1<smiles>CS(=O)(=O)OCOCOS(C)(=O)=O</smiles>

2
Herein we report the synthesis of several bis-pyridinium oximes including the common nerve agent antidotes. toxogonin and HI-6, by use of bis(methylsulfonoxymethyl) ether 2 . The ether 2 was prepared by a reported method. "The bis-pyridinium oximes such as toxogonin and HI-6 were prepared from the reactions of bis(methylsulfonoxymethyl) ether with 2-pyridinealdoxime 3, 4-pyridinealdoxime 4 and or isonicotinamide 5 at $\mathrm{rt}$. in $\mathrm{MeCN}$, and all reaction products were obtained as methanesulfonate salts (Scheme 1). para-Substituted pyridines $\mathbf{4}$ and $\mathbf{5}$ provided higher yields than ortho-substituted pyridine 3 . In these reactions. unreacted pyridines $3,4,5$ were also obtained as their 


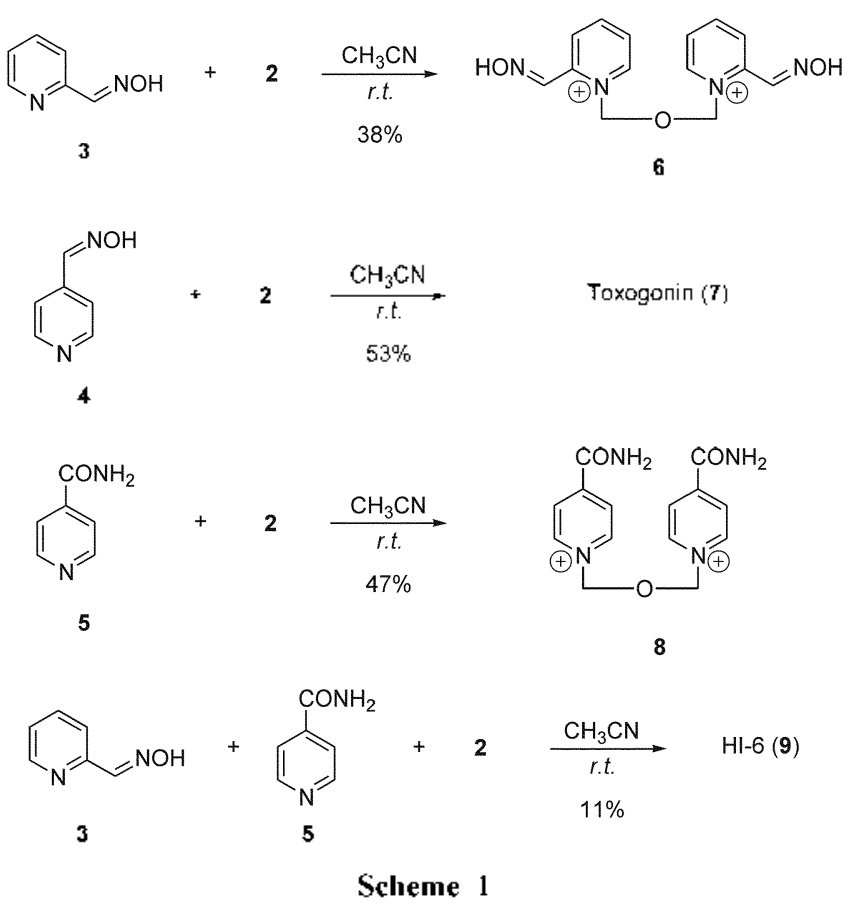

methanesulfonate salts, which were identified and easily separated from the mixture by washing with $\mathrm{EtOH}$. For the preparation of $\mathrm{HI}-6$, the ether 2 was reacted with pyridinaldoxime 3 followed by isonicotinamide 5 . Of the several possible products, bis-isonicotinamide 8 that is insoluble in $\mathrm{MeOH}$ was removed from the mixture by $\mathrm{MeOH}$ washing. The filtrate contained $1: 1$ mixture of 9 and a salt of 5, and the both compounds were not separable in various solvent systems. For the identification, the I : I mixture was passed through a Dowex resin to give $\mathrm{HCl}$ salts of 9 and 5 , and pure $\mathrm{HCl}$ salt of 9 was prepared by use of $\mathrm{BCME}$ as a known method. ' $\mathrm{H}$ NMR spectrum of the $\mathrm{HCl}$ salt of 9 and ${ }^{1} \mathrm{H}$ NMR spectrum of the methanesulfonate salt of 9 were quite similar each other except the presence of a methyl peak in the methanesulfonate salt 9 .

\section{Experimental Section}

All reactions were carried out under $\mathrm{N}_{2}$ atmosphere unless otherwise noted. $\mathrm{MeCN}$ was distilled from $\mathrm{CaH}_{2}$ prior to use. Organic extracts or filtrates were washed with brine, dried over anhydrous $\mathrm{Na}_{2} \mathrm{SO}_{4}$, and concentrated in vacuo. Flash chromatography was performed with Merck-EM lype 60 (230-400 mesh) silica gel (flash). 'H NMR spectra were measured by Varian Gemini $200 \mathrm{MHz}$ and Bruker AM-300 NMR spectrometers. Chemical shifts are reported in ppm (d) relative to JMS as internal standard. Mass spectrometric data determined by use of the electron impact (EIMS) method are reported as $\mathrm{m} / \mathrm{z}$ (relative intensity). Elemental analyses were performed with CE Instruments-ea 1110 Automatic Elemental Analyzer. Melting points were uncorrected.

1,1'-|Oxybis(methylene)|-bis|2-(hyd roxyimino)methyl|pyridinium dimethanesulfonate (6). To a solution of 2 -
Pyridinealdoxime $(3.91 \mathrm{~g}, 31.9 \mathrm{mmol})$ in $\mathrm{CH}_{i} \mathrm{CN}(20 \mathrm{ml})$ was added a mixture of bis(methanesulfonoxymethyl)ether (2) $(5.0 \mathrm{~g}, 21.3 \mathrm{mmol})$ in $\mathrm{CH}_{3} \mathrm{CN}(3.7 \mathrm{ml})$ by use of cannular needle at $0^{\circ} \mathrm{C}$. The mixture was stirred at $0{ }^{\circ} \mathrm{C}$ for $0.5 \mathrm{~h}$ followed by at $\mathrm{r} t$. for $20 \mathrm{~h}$. A precipitate was washed with $\mathrm{\Gamma} \mathrm{tOH}(12.5 \mathrm{ml}$ ) and dried in vacuo to give $6(2.90 \mathrm{~g}$. $38 \%$ ). Analytical sample was obtained by recrystallization from $\mathrm{MeOH},{ }^{1} \mathrm{H}$ NMR $\left(300 \mathrm{MH}, \mathrm{D}_{2} \mathrm{O}\right) \delta 2.60(\mathrm{~s}, 6 \mathrm{H}$, $\left.2 \mathrm{CH}_{3} \mathrm{SO}_{3}\right), 6.24\left(\mathrm{~s}, 4 \mathrm{H}_{2} 2 \mathrm{CH}_{2} \mathrm{O}\right), 7.87-7.92(\mathrm{~m}, 2 \mathrm{H}, \mathrm{ArH})$, 8.28 (d, $J=8.0 \mathrm{~Hz}, 2 \mathrm{H}, 2 \mathrm{CHN}$ ), 8.43-8.48 (m, 4H, ArH), $8.79(\mathrm{~d}, J=6.1 \mathrm{~Hz}, 2 \mathrm{H}, \mathrm{Ar}) ;{ }^{1 .} \mathrm{C}$ NMR $\left(75 \mathrm{MH}, \mathrm{D}_{2} \mathrm{O}\right) 40.1$. 87.2, 128.9, 129.5, 143.1, 146.5, 148.5, 149.7; Mass (FAB) m/e (rel, intensity) 479 (3), 383 (48), 307 (7), 287 (100), 257 (31), $239(10), 165(100), 119(100)$; mp 167-170 ${ }^{10} \mathrm{C}$.

1,1'-|Oxybis(methylene)]-bis|4-(hydroxyimino)methyl|pyridinium dimethanesulfonate (7). To a solution of 4Pyridinealdoxime $(0.33 \mathrm{~g}, 2.69 \mathrm{mmol})$ in $\mathrm{CH}_{3} \mathrm{CN}(9 \mathrm{ml}$. was added a mixture of bis(methanesulfonoxymethyl)ether (2) $(0.42 \mathrm{~g}, 1.79 \mathrm{mmol})$ in $\mathrm{CH}_{3} \mathrm{CN}(1 \mathrm{ml})$ by use of cannular needle at $0{ }^{\circ} \mathrm{C}$. The mixture was stirred at $0{ }^{\circ} \mathrm{C}$ for $0.5 \mathrm{~h}$ followed by at $r t$. for $20 \mathrm{~h}$. A precipitate was washed with Г. $\mathrm{tOH}(5 \mathrm{~mL})$ and dried in vacwo to give 7 (2.9 g. $38 \%)$. Analytical sample was obtained by recrystallization from $\mathrm{MeOH} .{ }^{\prime} \mathrm{H}$ NMR $\left(200 \mathrm{MHz}, \mathrm{D}_{2} \mathrm{O}\right) \delta 2.64\left(\mathrm{~s}, 6 \mathrm{H}, 2 \mathrm{CH}_{3} \mathrm{SO}_{3}\right)$, $6.05\left(\mathrm{~s}, 4 \mathrm{H}, 2 \mathrm{CH}_{2} \mathrm{O}\right), 8.14(\mathrm{~d}, J=7.3 \mathrm{~Hz}, 4 \mathrm{H}, \operatorname{ArH}), 8.25(\mathrm{~s}$, $2 \mathrm{H}, 2 \mathrm{CHN}), 8.84(\mathrm{~d}, J=6.5 \mathrm{~Hz}, 4 \mathrm{H}, \mathrm{ArH}) ;{ }^{\mathrm{I}} \mathrm{C}$ NMR $(75$ $\left.\mathrm{MHz}, \mathrm{D}_{2} \mathrm{O}\right) 38.8,87.1,125.3,144.0,146.4,151.7$; Mass (FAB) $\mathrm{m} / \mathrm{e}$ (rel. intensity) $479(7) .383(100), 287(25), 261$ (11), 231 (5), $142(22), 112(5) ; \mathrm{mp} 210-211^{\circ} \mathrm{C}$.

$1,1^{\prime}$-|Oxybis(methylene)|-bis|4-carbamoyl|pyridinium dimethanesulfonate (8). To a solution of isonicotinamide $(5.62 \mathrm{~g}, 46 \mathrm{mmol})$ in $\mathrm{CH}, \mathrm{CN}(20 \mathrm{~mL})$ was added a mixture of bis(methanesulfonoxymethyl)ether (2) (7.2 g. 30.7 minol) in $\mathrm{CH}_{3} \mathrm{CN}(3.7 \mathrm{~mL})$ by use of cannular needle at $0^{\circ} \mathrm{C}$. The mixture was stirred at $0{ }^{\circ} \mathrm{C}$ for $0.5 \mathrm{~h}$ followed by at $r t$. for 20 h. A precipitate was washed with $\mathrm{EtOH}(12.5 \mathrm{~mL})$ and dried in vacto to give $8(5.2 \mathrm{~g} .47 \%)$. ' $\mathrm{H} \mathrm{NMR}\left(300 \mathrm{MHz}, \mathrm{D}_{2} \mathrm{O}\right) \delta$ 2.60 (s, $\left.6 \mathrm{H}, 2 \mathrm{CH}_{3} \mathrm{SO}_{3}\right), 6.16\left(\mathrm{~s}, 4 \mathrm{H}, 2 \mathrm{CH}_{2} \mathrm{O}\right), 8.32$ (d, $J=6.8$ $\mathrm{Hz}, 4 \mathrm{H}, \mathrm{ArH}), 9.08$ (d, $J=6.8 \mathrm{~Hz}, 4 \mathrm{H}, \mathrm{ArH}) ;{ }^{1 .} \mathrm{C}$ NMR $(75$ $\left.\mathrm{MHz}, \mathrm{D}_{2} \mathrm{O}\right)$ 40.1, 88.4, 127.9, 146.0, 152.1, 167.1; Mass (FAB) m/e (rel. intensity) 479 (I l), $460(6), 383(100), 365$ (5), $307(55), 288(82), 261(69), 231(16), 154(100), 106$ (77); mp 205-206 ${ }^{\circ} \mathrm{C}$.

1-(2-Hydroxyiminomethyl-1-pyridino)-3-(4-carbamoyl1-pyridino)-2-oxapropane dimethanesulfonate (9). To a solution of 2-pyridinealdoxime (0.32 g. $2.5 \mathrm{mmol})$ in $\mathrm{CH}_{3} \mathrm{CN}(9 \mathrm{~mL})$ was added a mixture of bis(methanesulfonoxymethyl)ether (2) $(0.60 \mathrm{~g}, 2.5 \mathrm{mmol})$ in $\mathrm{CH}_{3} \mathrm{CN}(1 \mathrm{~mL})$ by use of double tip needle at $0^{\circ} \mathrm{C}$. 'The mixture was stirred at 0 ${ }^{\circ} \mathrm{C}$ for $0.5 \mathrm{~h}$ followed by at $n t$. for $3 \mathrm{~h}$. A solution of isonicotinamide $(0.32 \mathrm{~g} .2 .5 \mathrm{mmol})$ in $\mathrm{CH}_{3} \mathrm{CN}(9 \mathrm{~mL})$ was slowly added at $0{ }^{\circ} \mathrm{C}$. After stirring at $r t$. for $12 \mathrm{~h}$, a precipitate was collected and washed with $\mathrm{MeOH}(12 \mathrm{~mL})$ to give 8 . The filtrate was concentrated and the obtained solid was washed with $\mathrm{EtOH}(10 \mathrm{~mL})$ and dried in vacuo to give a mixture (0.2 $\mathrm{g}$ ) of 9 and 5 . The amount ratio of 9 and 5 
was $1: 1$. and 9 could be obtained $0.1+\mathrm{g}(11 \%) .{ }^{1} \mathrm{H}$ NMR (200 MHz. D 20 ) $\delta 2.62$ (s. $6 \mathrm{H} .2 \mathrm{CH}_{3} \mathrm{SO}_{3}$ ). 6.12 (s. $2 \mathrm{H}$. $\mathrm{CH}_{2} \mathrm{O}$ ). 6.25 (s. $2 \mathrm{H}, \mathrm{CH}_{2} \mathrm{O}$ ). $7.92-7.99$ (m, $1 \mathrm{H}$. $\mathrm{ArH}$ ), 8.298.35 (m, 3H. CHN and ArH), 8.44-8.55 (m. 2H. ArH). 8.88 (d. $J=6.0 \mathrm{~Hz} .1 \mathrm{H} . \mathrm{ArH}) .9 .05(\mathrm{~d} . J=6.6 \mathrm{~Hz}, 2 \mathrm{H}, \mathrm{ArH}$ ).

[4-Carbamoyl]pyridium methanesulfonate (salt of 5). To a solution of isonicotinamide $(1.00 \mathrm{~g}, 8.2 \mathrm{mmol})$ in $\mathrm{CH}_{3} \mathrm{CN}(10 \mathrm{~mL})$ was added a solution of methanesulfonic acid $(0.54 \mathrm{~mL} .8 .2 \mathrm{mmol})$ in $\mathrm{CH}_{3} \mathrm{CN}(1 \mathrm{~mL})$ at $0{ }^{\circ} \mathrm{C}$. After stirring at r.t. for $0.5 \mathrm{~h}$. A precipitate was washed with $\mathrm{CH}_{3} \mathrm{CN}$ and dried in vacto to give a salt of 5 as a white solid $(1.71$ g. $96 \%) .{ }^{1} \mathrm{H}$ NMR $\left(300 \mathrm{MHz} . \mathrm{CDCl}_{3}\right) \delta 2.60(\mathrm{~s}, 3 \mathrm{H}$. $\left.\mathrm{CH}_{3} \mathrm{SO}_{3}\right) .8 .15(\mathrm{~d} . J=6.8 \mathrm{~Hz} .2 \mathrm{H}, \mathrm{ArH}) .8 .76(\mathrm{~d} . J=6.8 \mathrm{~Hz}$. $2 \mathrm{H}, \mathrm{ArH})$; mp 199-202 ${ }^{\circ} \mathrm{C}$.

Acknowledgment. This work was supported by grants from the Ministry of Science and Technology in Korea and from Korea Science \& Engineering Foundation (R01-2001$00160)$

\section{References}

1. (a) Marrs. I. C. Pharmacol. Ther 1993. 58.51-66. (b) Dawson. R. M. J.Appl. Toxicol. 1994. 14. 317-331.

2. Bajgar. T. Acta Hed 1996. 39. 101-105.

3. (a) Leadbeater, L.: Inns, R. H.: Rylands, J. M. Fundam. Appt. Toxical $1985,5, \mathrm{~S} 225-231$.

4. (a) Thiermann, H; Seidl. S; Eyer, P. Int. J. Pharnt 1996. 137. 167-176. (b) Aas. P. Ent J. Pharntcol 1996. 301. 59-66. (c) Lallement. G.: Clarencon. D.: Brochier. G.: Baubichon. D.: Galonnier. M.: Blanchet. G.: Mestries. J. Pharmacol. Biochem. Behav: 1997. 56. 325-332.

5. Hagedorn. I. LSP 3.852.294, 1974.

6. (a) Burness. D. M.: Wright. C. J.; Perkins, W. C. J. Org Chem. 1977. +2. 2910-2913. (b) Wadsworth. D. H.: Vinal. R. S. ibid 1982. $47.1623-1626$. 